\title{
Corrosion and tribocorrosion behavior of Ti-alumina composites
} Elena Gordo ${ }^{1, a^{\star}}$, Roberto G. das Neves ${ }^{1, b}$, Begoña Ferrari' ${ }^{2, ~ c}$, Antonia Jimenez-Morales ${ }^{1, d}$, Andreia Lima ${ }^{3, e}$, Alexandra C. Alves ${ }^{3, f}$, Ana Maria Pinto $^{3,4,9}$ and Fatih Toptan ${ }^{3,4, h}$

\author{
${ }^{1}$ Department of Materials Science and Engineering, IQMAAB, University Carlos III of Madrid, Avda. \\ Universidad, 30, 28911 Leganés, Madrid, Spain \\ ${ }^{2}$ Institute of Ceramics and Glass, CSIC, c/Kelsen 5, 28049 Madrid \\ ${ }^{3}$ CMEMS-UMinho - Center for MicroElectroMechanical Systems - Universidade do Minho, Azurém, \\ 4800-058 Guimarães, Portugal \\ ${ }^{4}$ Universidade do Minho, Dept. Eng. Mecânica, Azurém, 4800-058 Guimarães, Portugal \\ aelena.gordo@uc3m.es, bquimicas82@gmail.com, 'bferrari@icv.csic.es, dtoni@ing.uc3m.es, \\ ea61939@alumni.uminho.pt, '⿳alexandra@dem.uminho.pt, ${ }^{9}$ anapinto@dem.uminho.pt, \\ hftoptan@dem.uminho.pt
}

\begin{abstract}
Keywords: Titanium, Alumina, Corrosion, Tribocorrosion, Colloidal processing, Biomaterials.
\end{abstract}
\begin{abstract}
This work focus on the corrosion and wear properties of titanium reinforced with $1 \%$ wt. alumina particles, produced by a combination of colloidal techniques and powder metallurgy. The alumina particles were added to control the grain growth of titanium during sintering, and simultaneously to increase hardness and wear resistance. Colloidal techniques permitted a homogeneous dispersion of alumina particles on the surface of fine Ti particles by the formulation of stable aqueous suspensions that were further processed by spray-dry to obtain spherical granules with improved compressibility. Ti-alumina samples were produced by uniaxial pressing of granules and vacuum sintering leading to materials with homogeneous microstructure, a reduction of grain size higher than $50 \%$ with respect to pure titanium, and a sensible increase in hardness. But the addition of ceramic particles can also have an influence on the corrosion behavior that is one of the most interesting properties of titanium alloys, and on wear resistance, that is one of the drawbacks of Ti. Moreover, the study of simultaneous action of wear and corrosion (tribocorrosion) is an area of highest interest in applications like biomedical or automotive. The corrosion behavior was evaluated by Electrochemical Impedance Spectroscopy (EIS) and Potentiodynamic Polarization (PP) in $\mathrm{NaCl}$ at two concentrations $(0.9 \%$ and $3.5 \%)$ and temperatures $\left(37{ }^{\circ} \mathrm{C}\right.$, and room temperature). Tribocorrosion tests were performed using a reciprocating ball-on-plate tribometer where a $10 \mathrm{~mm}$ diameter alumina ball was used as counter material, and $10 \mathrm{~N}$ normal load was applied during $30 \mathrm{~min}$ in the same concentrations and temperatures of $\mathrm{NaCl}$ as in the static corrosion tests. The results showed a clear improvement of wear resistance on the composite without reducing the corrosion behavior in both conditions.
\end{abstract}

\section{Introduction}

Titanium is recognized as the preferred metallic material for biomedical applications as implant prosthesis [1]. The prosthesis components are normally made by conventional metallurgy (wrought titanium) but there is an increasing interest on the use of powder metallurgy due to its inherent advantages such as high material yield, reduction of machining steps, and possibility of designing alloys with tailored compositions, among others. One of the major concerns of titanium for its use as prosthesis material is the poor wear resistance, leading to ion liberation into the surrounding tissues as well as the loosening of the prosthesis [2,3,4,5]. There are different strategies to increase the wear resistance of titanium for biomedical applications, most of them acting on the surface of the component $[1,6,7]$ whereas metal matrix composite (MMC) structures are yet to be fully explored. In this work, an approach based on MMCs is used, implemented by the combination of 
powder metallurgy and colloidal processing techniques. Colloidal techniques have been successfully used to process fine $\mathrm{Ti}$ powders to reduce the sintering temperature and time thus reducing the interstitial elements and grain size [8]. The poor compressibility of fine powders is overcome by producing highly packed granules of Ti particles by spray-dry of aqueous suspensions. These techniques also permit the homogeneous distribution of submicron or nano-sized particles avoiding the need of mechanical milling. Different ceramic particles, such as alumina, zircona or yttria, have been used to control grain growth during sintering [9] and it is expected to improve wear resistance of the titanium base material due to the hardness increment. Other authors have observed reductions on wear rate when titanium is reinforced with particles such as $\mathrm{TiC}$ or $\mathrm{TiB}$ $[10,11,12]$. However the introduction of ceramic particles creates heterogeneities on the microstructure that can deteriorate the corrosion behavior. On the other hand, the simultaneous action of corrosion and wear, defined as tribocorrosion, can result in a significantly higher material loss than that of the mechanical wear and corrosion individually. In biomedical devices, degradation products can interact with local tissues and eventually can produce an adverse response leading to implant failure $[13,14,15,16,17]$. This work studies the corrosion and tribocorrosion behavior of titanium reinforced with alumina particles produced by combination of colloidal techniques and powder metallurgy. Although the main focus application is biomedical implants, since titanium is being used in automotive and aerospace industries, the results of this study can be interesting for several applications.

\section{Experimental procedure}

Materials. The base material was elemental titanium powder, grade 2, with a spherical morphology and a mean particle size of $10 \mu \mathrm{m}$ (Ti 10), supplied by AP\&C Inc (Canada). The $\mathrm{Al}_{2} \mathrm{O}_{3}$ powder was supplied by Condea HPA05 (USA), had particle size $0.5 \mu \mathrm{m}$ average and a high purity of $99.99 \%$. The composition of the samples produced is $\mathrm{Ti}+1 \mathrm{wt} \% \mathrm{Al}_{2} \mathrm{O}_{3}$. Ti samples without reinforcement were also prepared as reference material, using a Ti powder from the same supplier with bigger particle size, $45 \mu \mathrm{m}$ (Ti45).

Processing. Suspensions of 50 vol. $\%$ of Ti 10 with 1 wt $\% \mathrm{Al}_{2} \mathrm{O}_{3}$ were fabricated in water using ammonium polyacrylate (PAA) as dispersant. After the powder was incorporated into water with the dispersant, high power ultrasound $(400 \mathrm{~W})$ was applied to break undesirable agglomerates and the slurries were kept under stirring for 1 hour. Polyvinyl alcohol (PVA, Aldrich) was used as binder. Rheological studies were made to adjust the solid content of the suspensions to reach the optimum viscosity values for spray-dry; the details can be found in previous studies [18]. The slurries were spray-dried using Labplant SD-05 equipment (UK). The main operating parameters, such as the temperatures at the inlet $\left(220^{\circ} \mathrm{C}\right)$ and at the exhaust $\left(100{ }^{\circ} \mathrm{C}\right)$, slurry pump rate $(2 \mathrm{l} / \mathrm{h})$, air flow rate $(38 \mathrm{~m} 3 / \mathrm{h})$, and atomizing nozzle design, were set to provide spherical granules. The granules obtained by spray-dry were processed via pressing and sintering. Pressing was performed using a double-action uniaxial die press into cylinders with a diameter of $16 \mathrm{~mm}$. Green compacts were sintered in vacuum at $1100{ }^{\circ} \mathrm{C}$ for 30 minutes. The reference material (elemental $\mathrm{Ti}$ samples) was produced by pressing and sintering in the same conditions as granules.

Corrosion and tribocorrosion tests. Before testing, the sintered samples were prepared to mirror finish following a standard metallographic route: specimens were ground using emery paper ( $\mathrm{SiC}$, silicon carbide) of different granulometry down to 1000 grit and then polished with $0.3 \mu \mathrm{m}$ alumina particle suspension and silica gel. After polishing, the samples were ultrasonically cleaned in propanol for 10 minutes and 5 minutes in distilled water.

Corrosion tests were performed by using a conventional three electrode cell containing $180 \mathrm{~mL}$ of 0.9 wt. $\% \mathrm{NaCl}$ at body temperature $\left(37^{\circ} \mathrm{C}\right)$. As reference electrode saturated calomel electrode (SCE) was used (all the potentials were measured vs. SCE), the counter electrode was a Pt electrode and the samples were used as working electrodes. First, the open circuit potential (OCP) was measured during two hours in order to stabilize the surface, followed by electrochemical impedance spectroscopy (EIS), with a range frequency of $10^{5}$ to $10^{-3} \mathrm{~Hz}$, an amplitude of $\pm 10 \mathrm{mV}$ and 10 
points per decade, and finally, potentiodynamic polarization from $-0.6 \mathrm{~V}$ to $1.5 \mathrm{~V}$ with a scan rate of $1 \mathrm{mV} / \mathrm{s}$. The tests were carried out using Gamry Potentiostat/Galvanostat (model Reference-600).

Tribocorrosion tests were performed in a triboelectrochemical cell installed on a reciprocating ball-on-plate tribometer (CETR-UMT-2) against a $10 \mathrm{~mm}$ diameter alumina ball (Ceratec) with stroke length of $3 \mathrm{~mm}$, frequency of $1 \mathrm{~Hz}$, sliding time of $30 \mathrm{~min}$ and a normal load of $10 \mathrm{~N}$. Tribocorrosion tests were performed in two electrolytes: (i) $0.9 \mathrm{wt} . \% \mathrm{NaCl}$ at body temperature $\left(37^{\circ} \mathrm{C}\right.$ ), and (ii) $3.5 \mathrm{wt} \% \mathrm{NaCl}$ at room temperature by using the same electrode configurations as used in the static corrosion tests. OCP was measured before, during and after the sliding, where the sliding started after stabilizing the OCP values. All the electrochemical measurements were performed using a Voltalab PGP201 potentiostat (Rodiometer Analytical, Copenhagen, Denmark) controlled by the VoltaMaster 4 software (Radiometer Analytical, Copenhagen, Denmark).

Characterization. The sintered samples were characterized by measuring density, oxygen content grain size and hardness (with a load of 30kg during 20 seconds with Officine Galileo Mod. D 200). The samples after the corrosion and tribocorrosion tests were examined with Leica DM2500 optical microscope (OM) and FEI Nova 200 field emission gun scanning electron microscope (FEG-SEM) equipped with EDAX, energy dispersive X-ray spectroscopy (EDS). After tribocorrosion tests, wear track profiles were obtained by using a high-resolution optical sensor (STIL Microtopograph CHR 150) and the wear volume loss values were calculated by following the procedure given elsewhere [19].

\section{Results and discussion}

Characterization of sintered samples. The main characteristics of sintered materials are presented in Table 1. The material containing alumina presents lower amount of porosity and smaller grain size leading to higher hardness values. Notice that the density is higher than $98 \%$ of the theoretical even though the low sintering temperature and time. The amount of oxygen is due to the introduction of alumina particles that enhance sintering due diffusion processes and restrain the grain growth by solution drag. The microstructure of both materials (Figure 1) is constituted only by equiaxial alfa grains.

Table 1- Characteristics of sintered materials.

\begin{tabular}{|c|c|c|c|c|c|c|c|c|}
\hline $\begin{array}{l}\text { Type of } \\
\text { powder }\end{array}$ & $\begin{array}{c}\text { Density } \\
\text { Pycnometer } \\
(\% \text { TD*) }\end{array}$ & $\begin{array}{c}\text { Density } \\
\text { Dimensions } \\
\text { (\% TD) }\end{array}$ & $\begin{array}{c}\text { Total } \\
\text { porosity } \\
(\%)\end{array}$ & $\begin{array}{c}\text { Open } \\
\text { porosity } \\
(\%)\end{array}$ & $\begin{array}{l}\text { Closed } \\
\text { porosity } \\
(\%)\end{array}$ & $\begin{array}{c}0 \\
\text { (wt\%) }\end{array}$ & $\begin{array}{c}\text { Mean } \\
\text { grain size } \\
(\mu \mathrm{m})\end{array}$ & $\begin{array}{c}\text { Hardness } \\
\left(\mathrm{HV}_{\mathbf{3 0}}\right)\end{array}$ \\
\hline Ti 45 & $95.69 \pm 0.001$ & $82.76 \pm 0.01$ & 17.24 & 12.93 & 4.31 & 0.66 & 100 & $209 \pm 12$ \\
\hline $\begin{array}{c}\mathrm{Ti}-\mathrm{Al}_{2} \mathrm{O}_{3} \\
(\mathrm{Granules} \text { of } \\
\mathrm{Ti} 10+1 \text { wt } \% \\
\left.\mathrm{Al}_{2} \mathrm{O}_{3}\right)\end{array}$ & $98.74 \pm 0.001$ & $96.29 \pm 0.01$ & 3.71 & 2,45 & 1.26 & 0.95 & 44 & $354 \pm 10$ \\
\hline
\end{tabular}

*TD (theoretical density) 

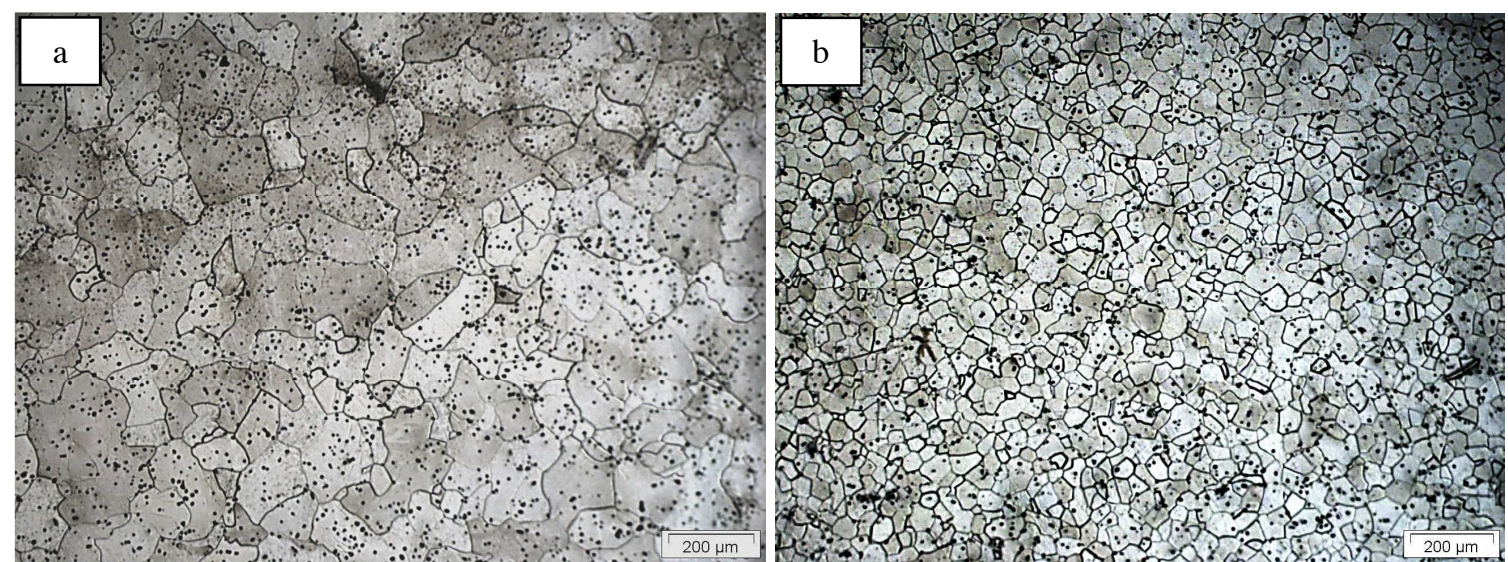

Figure 1. Microstructure of sintered samples obtained from (a) Ti45 as received powders and (b)

Ti10+1 wt $\%$ alumina from spray-dried powder. Samples sintered in vacuum at $1100{ }^{\circ} \mathrm{C}$ for 30 minutes.

Corrosion tests. Fig. 2 presents the electrochemical impedance spectra for titanium and $\mathrm{Ti}-\mathrm{Al}_{2} \mathrm{O}_{3}$ composite in the form of Nyquist and Bode diagrams. EIS spectra showed one semi-circle, corresponding to a time constant of the native oxide film. The impedance slightly increased with the addition of $\mathrm{Al}_{2} \mathrm{O}_{3}$ particles by presenting a slightly bigger diameter of the semi-circle. By analysing the Bode diagrams presented in Fig. 1b, constant values observed for $\mid \mathrm{ZI}$ in the high frequency range $\left(10^{2} \mathrm{~Hz}\right.$ to $\left.10^{5} \mathrm{~Hz}\right)$ where the phase angle is near $0^{\circ}$ corresponding to the response of the electrolyte resistance. For the both groups of samples, in low and middle frequency ranges, the phase angle presented values that approach $-90^{\circ}$ that is a typical capacitive behaviour of a compact oxide film. On the other hand, the high values of $\left.\mathrm{IZ}\right|_{\mathrm{f} \rightarrow 0}$ corresponds to the corrosion resistance of the material. In both cases, $\mathrm{Ti}-\mathrm{Al}_{2} \mathrm{O}_{3}$ composite presented slightly higher values when compared with unreinforced titanium.

(a)

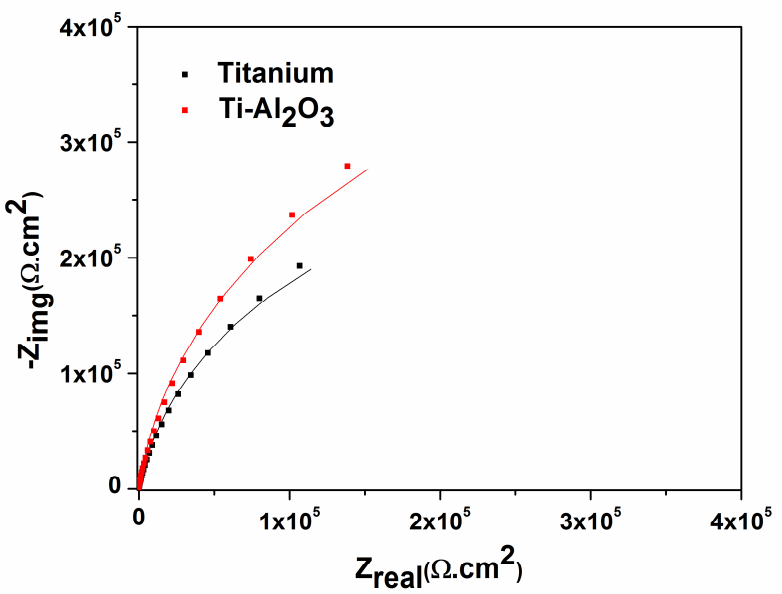

(b)

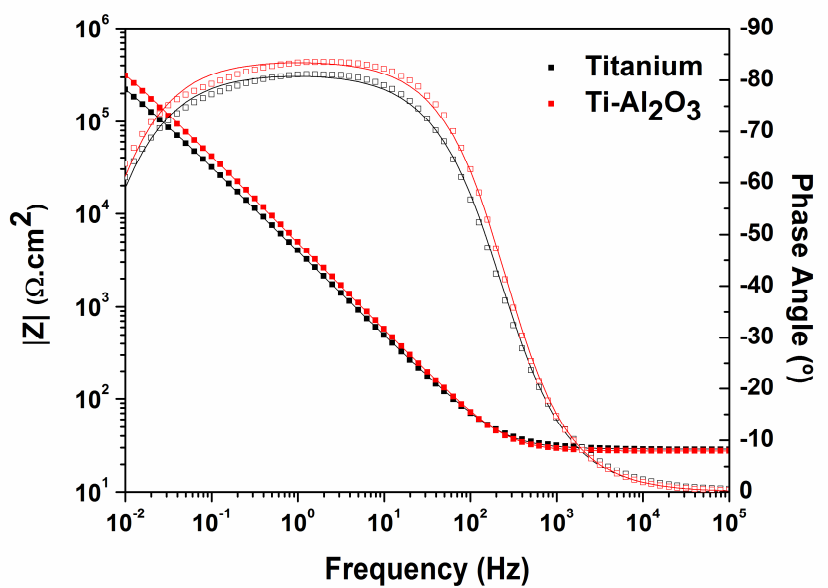

Figure 2. EIS spectra in the form a) Nyquist and b) Bode diagrams of experimental data, and fitted curves for titanium and $\mathrm{Ti}-\mathrm{Al}_{2} \mathrm{O}_{3}$ composite.

Figure 3 shows the equivalent circuit that was used to fit the experimental data for the titanium and $\mathrm{Ti}-\mathrm{Al}_{2} \mathrm{O}_{3}$ composite representing the native oxide film on the surface in contact with the electrolyte. The equivalent circuit contains electrolyte resistance, $\mathrm{R}_{\mathrm{e}}$, native oxide film resistance, $\mathrm{R}_{\mathrm{ox}}$, and constant phase element (CPE), $\mathrm{Q}_{\mathrm{ox}}$, accounting for the non-ideal capacitance of the native oxide film. 


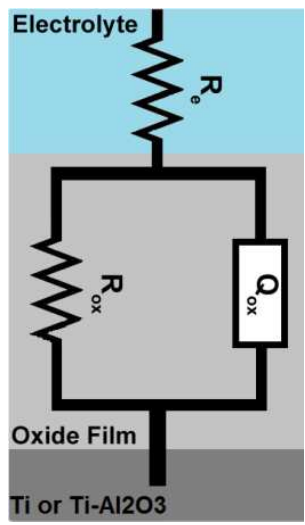

Figure 3. Equivalent circuit used for titanium and $\mathrm{Ti}-\mathrm{Al}_{2} \mathrm{O}_{3}$ composite where $\mathrm{R}_{\mathrm{e}}$ is the electrolyte resistance, $R_{o x}$ is the native oxide film resistance and $Q_{o x}$ is the $C P E$ of the native oxide film.

The impedance spectra were fitted to the corresponding equivalent circuit using Gamry Echem Analyst software (version 5.61). In order to allow the deviation of ideal behaviour of a capacitor, CPE was used in the fitting. The impedance of CPE is defined as as $Z_{C P E}=\left[Y_{0}(j w)^{n}\right]^{-1}$, where $-1 \leq n \leq 1$. When $n=1, n=0$, and $n=-1$, the CPE response corresponds to those of a capacitor, a resistor or inductor, respectively. When $\mathrm{n} \approx 1$, a non-ideal capacitor may be described by this element where the $\mathrm{n}$ value being influenced by the roughness of the surface and its heterogeneity. Both, titanium and $\mathrm{Ti}-\mathrm{Al}_{2} \mathrm{O}_{3}$ composite samples presented $\mathrm{n}$ values between 0.92 and 0.96. The quality of fitting was evaluated through their goodness of fitting values and the proposed models described adequately the behaviour of both groups with a goodness of fitting bellow $10^{-4}$. As can be seen on the values of the fitting results given in Table 2, titanium and $\mathrm{Ti}-\mathrm{Al}_{2} \mathrm{O}_{3}$ composite presented similar $\mathrm{Q}_{\mathrm{ox}}$ values of the oxide film indicating similar protection properties of the oxide passive film formed. Besides, $\mathrm{Ti}-\mathrm{Al}_{2} \mathrm{O}_{3}$ composite samples presented slightly higher resistance to corrosion compared with the unreinforced titanium indicated by a slightly bigger diameter of the semi-circle presented in the Nyquist diagram and higher values of IZI at low frequencies, indicating higher impedance of the system (Fig. 2).

Table 2. Equivalent circuit parameters obtained from EIS data for titanium and $\mathrm{Ti}-\mathrm{Al}_{2} \mathrm{O}_{3}$ composite.

\begin{tabular}{|c|c|c|c|}
\hline Material & $\begin{array}{c}\mathrm{R}_{\mathrm{sol}} \\
\left(\Omega . \mathrm{cm}^{2}\right)\end{array}$ & $\begin{array}{c}\mathrm{R}_{\mathrm{ox}} \\
\left(\times 10^{5} \Omega . \mathrm{cm}^{2}\right)\end{array}$ & $\begin{array}{c}\mathrm{Q}_{\mathrm{ox}} \\
\left(\times 10^{-6} \mathrm{~s}^{n} . \Omega^{-1} \cdot \mathrm{cm}^{-2}\right)\end{array}$ \\
\hline $\mathrm{Ti} 45$ & $29.44 \pm 2.51$ & $5.47 \pm 1.11$ & $4.63 \pm 0.83$ \\
\hline $\mathrm{Ti}-\mathrm{Al}_{2} \mathrm{O}_{3}$ & $27.39 \pm 0.31$ & $8.28 \pm 2.91$ & $4.07 \pm 0.34$ \\
\hline
\end{tabular}

Figure 4 presents the potentiodynamic polarization curves for titanium and composite samples. In both cases, the curves exhibited three regions. The first region corresponds to the cathodic domain, which includes all the potentials bellow the corrosion potential $\left(\mathrm{E}_{(\mathrm{i}=0)}\right)$, in which the current density is given by the reduction of water and dissolved oxygen. The second region corresponds to the active region where corrosion potential lies between $\mathrm{E}_{(\mathrm{i}=0)}$ and $0 \mathrm{~V}$. The third region corresponds to the passive domain and is above $0 \mathrm{~V}$. In this domain, there is a passive film formation. This behavior is well known for passive metals. From this curves it is possible to extract by Tafel extrapolation several parameters like corrosion potential $\left(\mathrm{E}_{(\mathrm{i}=0)}\right)$, corrosion current density $\left(\mathrm{i}_{\text {corr }}\right)$ and passivation current density ( $i_{\text {pass }}$ ) (Table 3 ). From this data it is possible to see that the difference between the materials was not significant, which means that the corrosion behavior of titanium and composite is very similar. From OCP curves it can be seen that particle addition did not affect the corrosion tendency of titanium. The Nyquist and Bode diagram showed the same result, since for 
both samples the results are very similar and from the shape of the phase angle there is no evidence for localized corrosion and galvanic coupling effect.

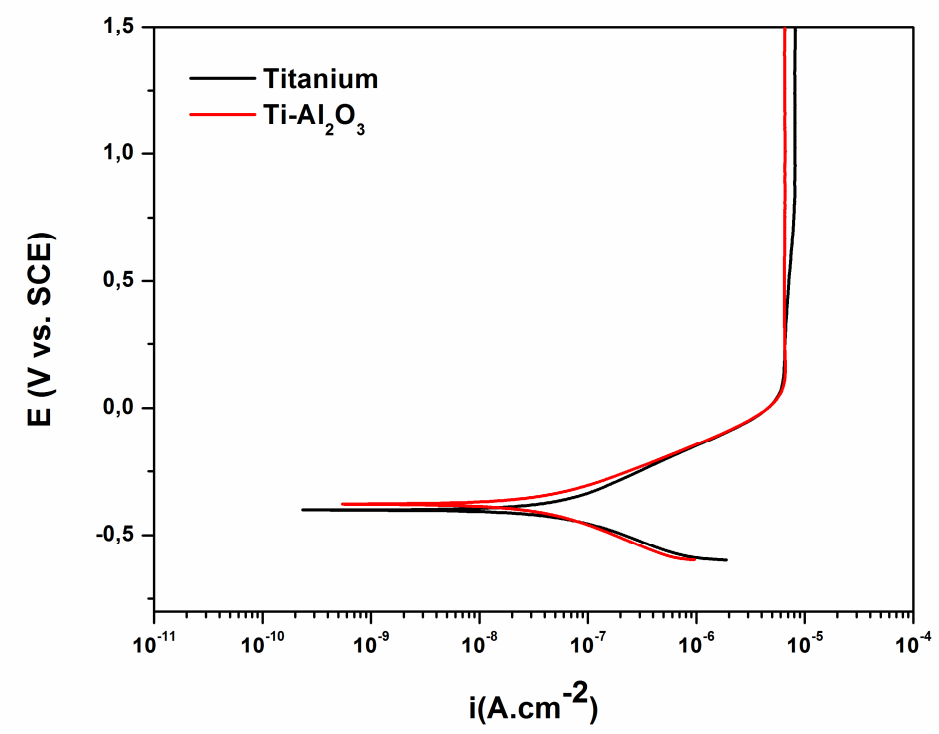

Figure 4. Potentiodynamic polarization curves for Ti and $\mathrm{Ti}-\mathrm{Al}_{2} \mathrm{O}_{3}$

Table 3. Corrosion data obtained from potentiodynamic tests.

\begin{tabular}{|c|c|c|c|}
\hline Material & $\begin{array}{c}\mathrm{E}_{(\mathrm{i}=0)} \\
(\mathrm{V})\end{array}$ & $\begin{array}{c}\mathrm{i}_{\text {corr }} \\
\left(\times 10^{-8} \mathrm{~A} \cdot \mathrm{cm}^{-2}\right)\end{array}$ & $\begin{array}{c}\mathrm{i}_{\text {pass }} \\
\left(\times 10^{-6} \mathrm{~A} \cdot \mathrm{cm}^{-2}\right)\end{array}$ \\
\hline $\mathrm{Ti} 45$ & $-0.39 \pm 0.02$ & $6.82 \pm 2.24$ & $7.73 \pm 0.95$ \\
\hline $\mathrm{Ti}-\mathrm{Al}_{2} \mathrm{O}_{3}$ & $-0.40 \pm 0.02$ & $4.75 \pm 2.10$ & $6.52 \pm 0.10$ \\
\hline
\end{tabular}

The evolution of OCP before, during and after the sliding is shown in Figure 5 together with the evolution of coefficient of friction (COF) with time. When sliding starts, the OCP immediately dropped down to the values around $-0.7 \mathrm{~V}$ for both samples and conditions, which indicates the damage on the passive film and the exposure of the fresh surface to the electrolyte $[19,20,21]$. In both samples and conditions, when sliding stopped, OCP values rapidly increased up to near the initial values due to re-passivation of the damaged passive film $[19,21]$. When two different concentrations of the electrolyte are compared, it was observed that the $\mathrm{NaCl}$ concentration did not create a significant difference on the potential values recorded under sliding for the composite samples, however, $\mathrm{Ti}$ samples tested in increased $\mathrm{NaCl}$ concentration presented relatively lower values under sliding as compared to the other samples. On the other hand, both materials presented very similar values and evolution of COF during sliding. 


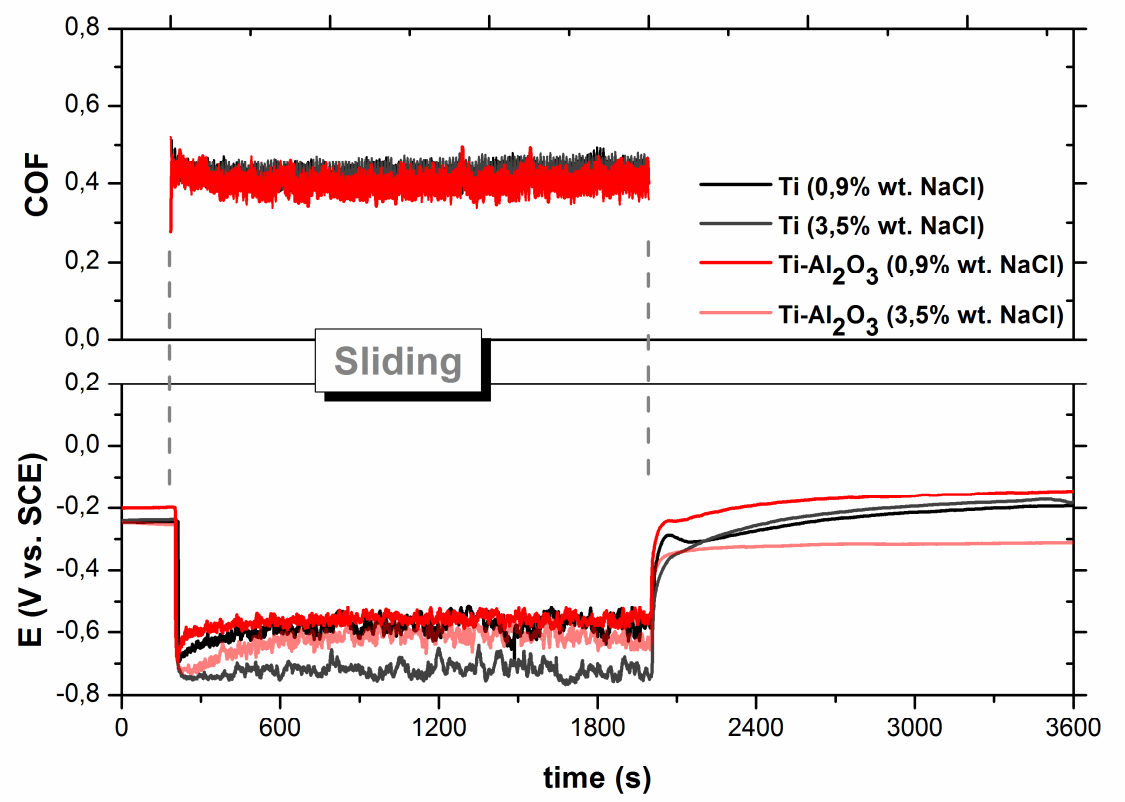

Figure 5. Evolution of COF and OCP in $\mathrm{NaCl}$ electrolytes for $\mathrm{Ti}$ and $\mathrm{Ti}-\mathrm{Al}_{2} \mathrm{O}_{3}$.

Figure 6 shows the representative 2D wear track profiles taken from the centre of the wear tracks of titanium and $\mathrm{Ti}-\mathrm{Al}_{2} \mathrm{O}_{3}$ composite tested in 0.9 and $3.5 \%$ wt. $\mathrm{NaCl}$. It can be observed that titanium samples presented deeper wear tracks. Total wear volume loss values for both groups of samples and for the different $\mathrm{NaCl}$ concentrations are given in Table 4. Composite samples presented lower wear loss values in both electrolytes, with a reduction close to $60 \%$ in both cases. According to the Archard's equation, wear loss is inversely proportional to the hardness of the testing material. Therefore, the difference on total wear volume loss values between titanium and $\mathrm{Ti}-\mathrm{Al}_{2} \mathrm{O}_{3}$ composite can be explained by the altered matrix microstructure, and the increased hardness of the $\mathrm{Ti}_{-} \mathrm{Al}_{2} \mathrm{O}_{3}$ composite. On the other hand, the results also showed that $\mathrm{NaCl}$ concentration did not create a significant influence on the wear volume loss for both samples.

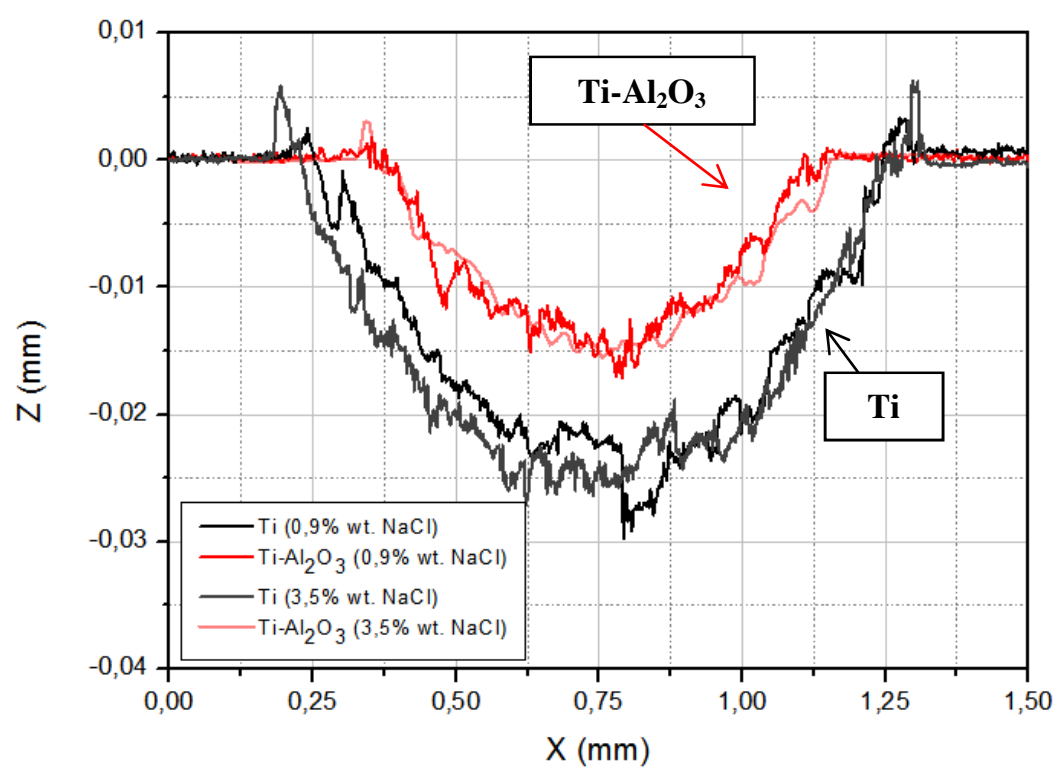

Figure 6: Wear track profiles for titanium and $\mathrm{Ti}^{-} \mathrm{Al}_{2} \mathrm{O}_{3}$ composite tested in $0.9 \%$ wt. and $3.5 \%$ wt. $\mathrm{NaCl}$. 
Table 4. Wear volume loss values for titanium and $\mathrm{Ti}-\mathrm{Al}_{2} \mathrm{O}_{3}$ composite.

\begin{tabular}{|c|c|c|}
\hline \multirow{2}{*}{ Material } & \multicolumn{2}{|c|}{ Wear Volume $\left(\times 10^{-2} \mathrm{~mm}^{2}\right)$} \\
\cline { 2 - 3 } & $0.9 \%$ wt. $\mathrm{NaCl}$ & $3.5 \%$ wt. NaCl \\
\hline $\mathrm{Ti} 45$ & $6.35 \pm 0.42$ & $6.61 \pm 0.14$ \\
\hline $\mathrm{Ti}-\mathrm{Al}_{2} \mathrm{O}_{3}$ & $2.72 \pm 0.11$ & $2.64 \pm 0.31$ \\
\hline
\end{tabular}

Figure 7 presents the SEM images of the mating worn surfaces taken after tribocorrosion tests performed in $0.9 \%$ wt. $\mathrm{NaCl}$ solution, together with the EDS spectra of the counter material. Both samples presented sliding grooves as parallel to the sliding direction, together with adhered $/ \mathrm{mixed}$ oxide patches [19]. Titanium oxides may form on the worn surfaces due to the repetitive material transfer between the sliding surfaces and they can play either a protective role or if these oxide patches reach a critical thickness, they can break up resulting in third body abrasion [22,23]. When two materials compared, it can be seen on the images that the effect of oxidational wear were much severe on the unreinforced titanium samples as compared to the composite samples. On the other hand, unreinforced titanium samples suffered more plastic deformation as compared to the composite samples. These differences between the samples can be explained by the reduced grain size and increased hardness on the composite samples resulting in less plastic deformation, increased resistance to abrasion and therefore less formation of wear debris and oxide patches. Accordingly, the worn counter material surface corresponding to the unreinforced samples presented bigger wear scars as compared to the ones obtained from the composites. Additionally, the analysis of both counter material surfaces proved the transfer of titanium from the samples pointing the adhesive wear. Thus, the wear mechanism can be mainly suggested as the combination of abrasive, adhesive and oxidational wear. Similar wear mechanism was also observed for the samples tested under $3.5 \%$ wt. $\mathrm{NaCl}$ solution.
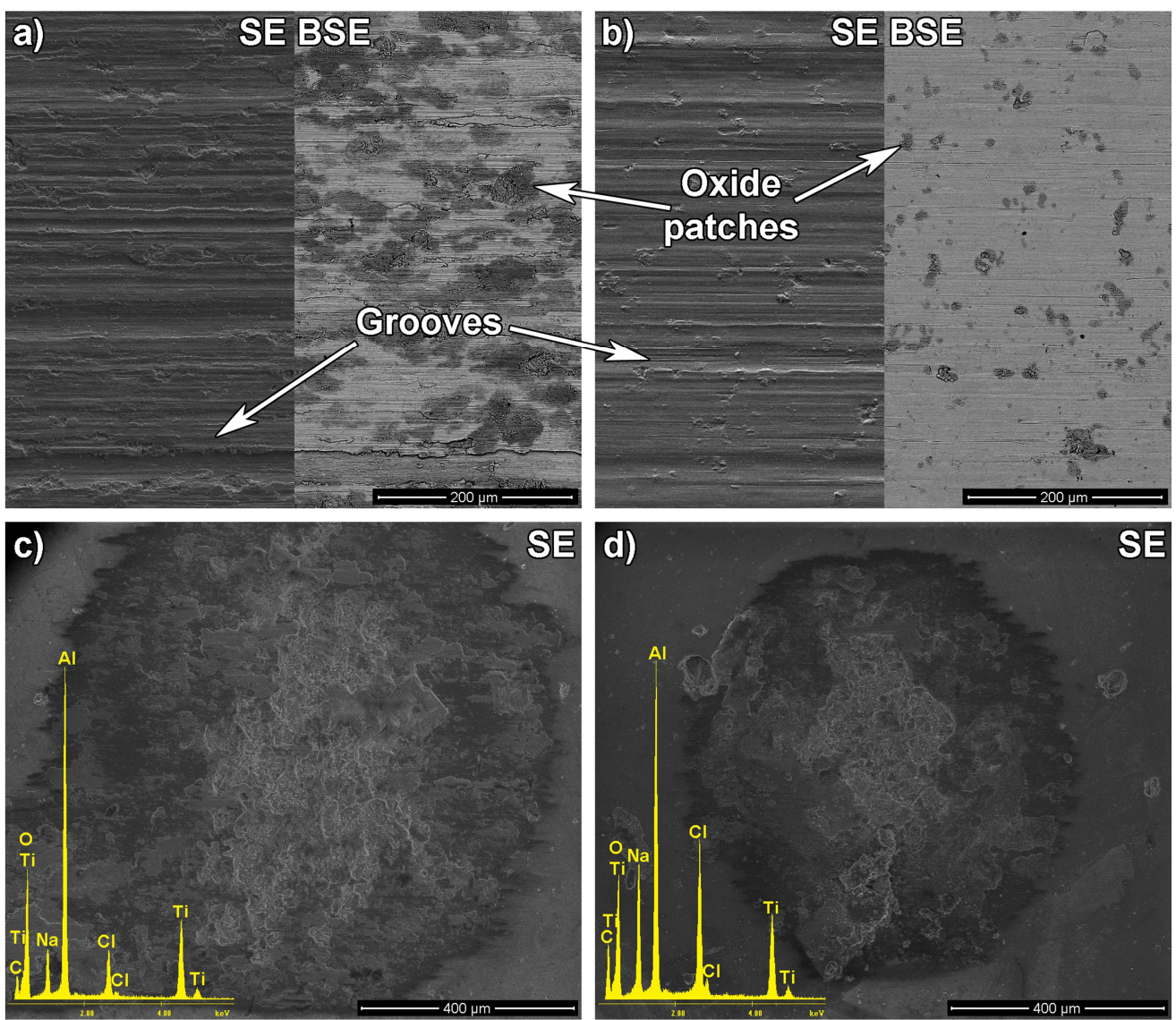

Figure 7. SEM images of a) Ti, b) Ti- $\mathrm{Al}_{2} \mathrm{O}_{3}$ samples and corresponding counter material surfaces and EDS spectra to c) $\mathrm{Ti}$, and d) $\mathrm{Ti}-\mathrm{Al}_{2} \mathrm{O}_{3}$. 


\section{Summary}

The corrosion behavior of both $\mathrm{Ti}$ and $\mathrm{Ti}-\mathrm{Al}_{2} \mathrm{O}_{3}$ composite is similar, meaning that the introduction of alumina particles have no a detrimental effect from the point of view of the corrosion behavior.

The tribocorrosion tests permit to affirm that both $\mathrm{Ti}$ and $\mathrm{Ti}-\mathrm{Al}_{2} \mathrm{O}_{3}$ presented very similar electrochemical (evolution of OCP) and tribological (evolution of COF) behavior under sliding in $0.9 \%$ wt. $\mathrm{NaCl}$ solution. However, unreinforced samples presented slightly lower OCP values as compared to the composite, while sliding under $3.5 \% \mathrm{wt}$. $\mathrm{NaCl}$.

The concentration of the electrolyte did not create a significant difference on the total wear volume loss for both samples.

Ti- $\mathrm{Al}_{2} \mathrm{O}_{3}$ composites exhibited a reduction of up to $60 \%$ in the wear volume loss values as compared to the unreinforced $\mathrm{Ti}$, indicated a better resistance to wear in both $\mathrm{NaCl}$ solutions.

\section{Acknowledgments}

Authors acknowledge funds provided by Spanish Government (MINECO) through the R\&D project MAT2012-38650-C02-01, regional government of Madrid through the program MULTIMATCHALLENGE, ref. S2013/MIT-2862, and The Calouste Gulbenkian Foundation through "Programa de Mobilidade Académica para Professores". The authors also would like to thank Prof. Pierre Ponthiaux (École Centrale Paris, France) for the provision of the microtopography facilities.

\section{References}

[1] M. Geetha, A.K. Singh, R. Asokamani, A.K. Gogia. Ti based biomaterials, the ultimate choice for orthopaedic implants - A review. Progress in Materials Science 54 (2009) 397-425.

[2] M. Bryant, R. Farrar, R. Freeman, K. Brummitt, J. Nolan, A. Neville, Galvanically enhanced fretting-crevice corrosion of cemented femoral stems, J. Mech. Behav. Biomed. Mater. 40 (2014) 275-286.

[3] M.P. Licausi, A. Igual Muñoz, V. Amigó Borrás, Influence of the fabrication process and fluoride content on the tribocorrosion behaviour of Ti6Al4V biomedical alloy in artificial saliva, $\mathrm{J}$. Mech. Behav. Biomed. Mater. 20 (2013) 137-48.

[4] C.E.B. Marino, L.H. Mascaro, EIS characterization of a Ti-dental implant in artificial saliva media: dissolution process of the oxide barrier, J. Electroanal. Chem. 568 (2004) 115-120.

[5] M.A. Arenas, A. Conde, J.J. Damborenea, The Role of Mechanically Activated Area on Tribocorrosion of CoCrMo, Metall. Mater. Trans. A. 44 (2013) 4382-4390.

[6] M. Niinomi, Mechanical biocompatibilities of titanium alloys for biomedical applications. Journal of the mechanical behaviour of biomedical materials I (2008) 30-42.

[7] Xuanyong Liu et al, Surface modification of titanium, titanium alloys, and related materials for biomedical applications. Materials Science and Engineering R 47 (2004) 49-121

[8] R. G. Neves, B. Ferrari, A. J. Sanchez-Herencia, and E. Gordo, Colloidal approach for the design of Ti powders sinterable at low temperature, Mater. Lett., 107 (2013) 75-78.

[9] R. G. Neves, B. Ferrari, A. J. Sanchez-Herencia, and E. Gordo, Design of Ti Microstructure by Addition of Ceramic Particles by Colloidal Techniques. PM Lightweight Materials, Proceedings of the EuroPM2014, Ed. EPMA.

[10] J.-S. Kim, K.-M. Lee, D.-H. Cho, Y.-Z. Lee, Fretting wear characteristics of titanium matrix composites reinforced by titanium boride and titanium carbide particulates, Wear. 301 (2013) 562568.

[11] Y. Qin, L. Geng, D. Ni, Dry sliding wear behavior of extruded titanium matrix composite reinforced by in situ TiB whisker and TiC particle, J. Mater. Sci. 46 (2011) 4980-4985. 
[12] I.Y. Kim, B.J. Choi, Y.J. Kim, Y.Z. Lee, Friction and wear behavior of titanium matrix (TiB+TiC) composites, Wear. 271 (2011) 1962-1965.

[13] M.T. Mathew, P. Srinivasa Pai, R. Pourzal, A. Fischer, M.A. Wimmer, Significance of Tribocorrosion in Biomedical Applications: Overview and Current Status, Adv. Tribol. 2009 (2009) $1-12$.

[14] S. Mischler, Triboelectrochemical techniques and interpretation methods in tribocorrosion: A comparative evaluation, Tribol. Int. 41 (2008) 573-583.

[15] M.A. Arenas, A. Conde, J.J. Damborenea, The Role of Mechanically Activated Area on Tribocorrosion of CoCrMo, Metall. Mater. Trans. A. 44 (2013) 4382-4390.

[16] J. Chen, F. Yan, Tribocorrosion behaviors of Ti-6Al-4V and Monel K500 alloys sliding against 316 stainless steel in artificial seawater, Trans. Nonferrous Met. Soc. China. 22 (2012) 1356-1365.

[17] Y. Liao, R. Pourzal, M.A. Wimmer, J.J. Jacobs, A. Fischer, L.D. Marks, Graphitic tribological layers in metal-on-metal hip replacements, Science. 334 (2011) 1687-90.

[18] R.G. Neves, B.ferrari, A.J.Sanchez-Herencia, C.Pagnoux, E.Gordo. Role of stabilizers in the design of Ti aqueous suspensions for pressure slip casting. Powder Technology, 263 (2014) 81-88.

[19] Z. Doni, A.C. Alves, F. Toptan, J.R. Gomes, A. Ramalho, M. Buciumeanu, et al., Dry sliding and tribocorrosion behaviour of hot pressed CoCrMo biomedical alloy as compared with the cast CoCrMo and Ti6Al4V alloys, Mater. Des. 52 (2013) 47-57.

[20] B.L. Lü, W.L. Zhou, G.Q. Chen, First-principles study on influence of alloying elements on electrochemical stability of cobalt-base alloys, Mater. Corros. 63 (2012) 735-738.

[21] J. Chen, F.Y. Yan, B.B. Chen, J.Z. Wang, Assessing the tribocorrosion performance of Ti-6Al4V, 316 stainless steel and Monel K500 alloys in artificial seawater, Mater. Corros. 64 (2013) 394401.

[22] T.C. Yap, N.S.M. El Tayeb, P.V. Brevern, K.S. Sim, Correlation of wear debris morphology and wear mechanism of Ti-5Al-4V-0.6Mo-0.4Fe slides against tungsten carbide under dry and cryogenic conditions, Int. J. Surf. Sci. Eng. 5 (2011) 463.

[23] T.F.J. Quinn, Review of oxidational wear: Part I: The origins of oxidational wear, Tribol. Int. 16 (1983) 257-271. 